\title{
Design of Miniature Planar Antennas for 5G Systems
}

\author{
Bousalah Fayza \\ Telecommunication Department, Université Abou-Bekr Belkaid, Tlemcen, Algeria
}

Email address:

Bousalah.fayza@gmail.com

To cite this article:

Bousalah Fayza. Design of Miniature Planar Antennas for 5G Systems. Advances in Wireless Communications and Networks. Vol. 7, No. 1, 2021, pp. 1-8. doi: 10.11648/j.awcn.20210701.11

Received: November 26, 2020; Accepted: December 22, 2020; Published: April 7, 2021

\begin{abstract}
The objective of this work is the design and simulation of an antenna based on metamaterials in order to miniaturize the dimensions of planar antennas. Metamaterials have been on the rise in recent years. The new properties make it possible to envisage the realization of new electronic components with new functions. Metamaterials are artificial materials designed for different telecommunications applications in order to improve the performance of antennas in terms of efficiency, compactness and miniaturization of structures. The use of these materials offers advantages such as reduction in weight and bulk, which is beneficial for their integration into $5 \mathrm{G}$ telecommunications and telephony systems. The fifth generation $5 \mathrm{G}$ mobile network is a set of emerging global telecommunications standards, typically using high frequency spectrum, to provide network connectivity with reduced latency and higher speed and capacity than the forerunners. It is argued that the recurring communication infrastructure is very inefficient in energy and that $5 \mathrm{G}$ should be designed to solve this problem, increasing energy efficiency by several orders of magnitude. To meet the demands of 5G, we need radically new network architectures and technologies, such as heterogeneous ultra-dense network, massive multi-output MIMO, and millimeter wave communications. Our goal is to achieve a planar antenna based on metamaterials which must operate at the resonance frequency of $5 \mathrm{G}$ which is $\mathrm{f}=3.5 \mathrm{GHz}$ by the CST Studio Suit electromagnetic design and simulation software and Matlab calculation.
\end{abstract}

Keywords: Planar Antenna, Patch Antenna, Metamaterials, SRR, CSRR, Millimeter Band, 5G Systems, Ansoft HFSS, CST-MWS, Matlab

\section{Introduction}

In order to miniaturize planar antennas; we used miniaturization techniques based on metamaterial technologies. These have been gaining momentum in recent years $[1,2]$. The use of these materials offers advantages such as reduction in weight and bulk, which is beneficial for their integration into electronic systems such as telecommunications systems for 5G [3]. Our work consists of giving an overview on planar antennas and the mechanism of their operations based on metamaterials, we will propose a design approach for a patch antenna deposited on a monolayer substrate by placing a CSRR cell based on it above. metamaterials working in millimeter wave. Subsequently, we will do a synthesis study to extract the various parameters influencing its electromagnetic behavior. The studied and designed antenna is intended to be used for 5G [4] telecommunications and telephone applications in the [3.3-3.8] $\mathrm{GHz}$ frequency band.
This article presents a concrete case of the design of a rectangular printed antenna, in order to study, design, simulate, characterize and analyze the various parameters of this antenna. This project consists of developing antennas capable of radiating at the frequency of $3.5 \mathrm{GHz}$, which could be used in a very large number of applications of telecommunications systems currently for $5 \mathrm{G}[5,6]$.

The objective of our work is to miniaturize the dimensions of the initial planar antenna in order to understand the influences of the square CSRR complementary split-ring resonator cells on the planar antennas. First, we modeled and designed the rectangular patch antenna from the dimensions obtained by Maxwell's electromagnetic equations under the Matlab environment. Next, we applied the CSRR cells on the patch antenna to make a parametric study of the different geometric shapes and locations of the CSRR cells on the patch and the ground plane. The various results of simulations of the "S11" reflection and "S21" transmission coefficients are obtained by the electromagnetic software CST are satisfactory and promising. 


\section{Characteristics of Planar Antennas}

The principle is to design a patch antenna which must operate at the resonant frequency $3.5 \mathrm{GHz}$, with a reflection coefficient of less than $-10 \mathrm{~dB}$. The principle is to design a patch antenna which must operate at the resonant frequency $3.5 \mathrm{GHz}$, with a reflection coefficient of less than $-10 \mathrm{~dB}$. To perform the various calculations of the dimensions of the rectangular patch antenna, we used the permittivity of the substrate $\varepsilon r=4.3$ with a thickness of $\mathrm{h}=1.56 \mathrm{~mm}[7,8]$.

\subsection{Theoretical Calculations of the Dimensions of the Rectangular Patch Antenna}

The values characterizing the different elements of the antenna are given as follows:

1. Dielectric permittivity of the substrate (FR-4 "Fire Retardant"): $\varepsilon r=4.3$

2. Height of dielectric substrate: $\mathrm{hs}=1.56 \mathrm{~mm}$

3. Desired resonance frequency $(5 \mathrm{G}): \mathrm{fr}=3.5 \mathrm{GHz}$

4. Adaptation to $50 \mathrm{Ohm}$

5. Power supply by microstrip line

6. Metallization thickness: $\mathrm{h}=0.035 \mathrm{~mm}$

To perform the various calculations of the dimensions of the rectangular patch antenna, we used the permittivity of the substrate $\varepsilon r=4.3$ with a thickness of $\mathrm{h}=1.56 \mathrm{~mm}$.

1) Calculate the patch width $\mathrm{Wp}$ :

$$
\mathrm{Wp}=\frac{C}{2 * f r * \sqrt{\frac{\varepsilon \mathrm{r}+1}{2}}}
$$

2) Calculation of effective dielectric constant greff:

$$
\varepsilon_{\text {reff }}=\frac{\varepsilon \mathrm{r}+1}{2}+\frac{\varepsilon \mathrm{r}-1}{2} *\left[1+12 * \frac{h}{\mathrm{w}}\right]^{-\frac{1}{2}}
$$

3) Calculate the effective length:

$$
\text { Leff }=\frac{C}{2 * f r * \sqrt{\varepsilon r e f f}}
$$

4) Extension length $(\Delta L)$ :

$$
\Delta L=0.412 * \mathrm{~h} * \frac{(\varepsilon e f f+0.3)\left(\frac{\mathrm{w}}{\mathrm{h}}+0.264\right)}{(\varepsilon e f f-0.258)\left(\frac{\mathrm{w}}{\mathrm{h}}+0.8\right)}
$$

5) Calculate the patch length (Lp):

$$
\mathrm{Lp}=\mathrm{L}_{\mathrm{eff}}-2 * \Delta l
$$

6) Feed length calculation (LL):

$$
\mathrm{LL}=\frac{C}{2 * f r}
$$

7) Calculation of substrate length ( $\mathrm{Lg})$ :

$$
\mathrm{Lg}=\mathrm{Lp}+6^{*} \mathrm{~h}+\mathrm{LL}
$$

8) Calculate the width of the substrate $(\mathrm{Wg})$ :

$$
\mathrm{Wg}=\mathrm{Wp}+6^{*} \mathrm{~h}
$$

9) Dimension of the transmission line $W_{0}=3.058 \mathrm{~mm}$. Table 1 shows the different parameters of the patch antenna.

Table 1. Dimensions of the patch antenna parameters.

\begin{tabular}{lllllll}
\hline $\boldsymbol{W}(\mathbf{m m})$ & $\varepsilon_{e}$ & $\boldsymbol{L}_{\boldsymbol{e}}(\mathbf{m m})$ & $\Delta \boldsymbol{L}(\mathbf{m m})$ & $\boldsymbol{L}(\mathbf{m m})$ & $\boldsymbol{L}_{L}(\mathbf{m m})$ & $\boldsymbol{L}_{\boldsymbol{g}}(\mathbf{m m})$ \\
\hline 26.32 & 3.9214 & 12.75 & 0.6915 & 20.40 & 42 & 71.76 \\
\hline
\end{tabular}

\subsection{Design and Simulation Results of the Rectangular Patch Antenna with Notches}

Figure 1a shows a rectangular patch antenna with notches, the latter are used for better adaptation of the antenna to the resonant frequency $3.5 \mathrm{GHz}$. Figure $1 \mathrm{~b}$ gives the simulation result of the reflection coefficient $\mathrm{S} 11=-29 \mathrm{~dB}$ as a function of the frequency $\mathrm{f}=3.51 \mathrm{GHz}$. Figure $1 \mathrm{c}$ shows the radiation pattern of the antenna. Figure 1d represents the directivity of the antenna, the angles $\mathrm{phi}=90^{\circ}$ and $\mathrm{Theta}=270^{\circ}$ with a gain of $6.2 \mathrm{~dB}$, which shows that the antenna is directional.

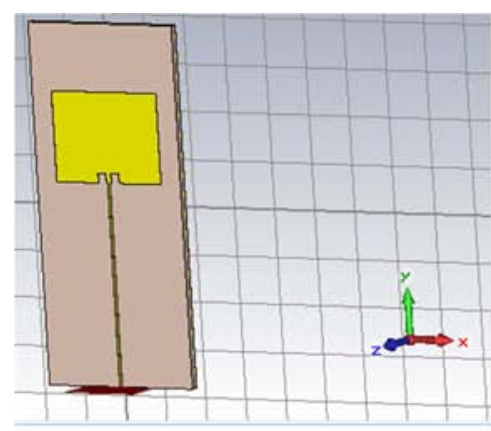

a

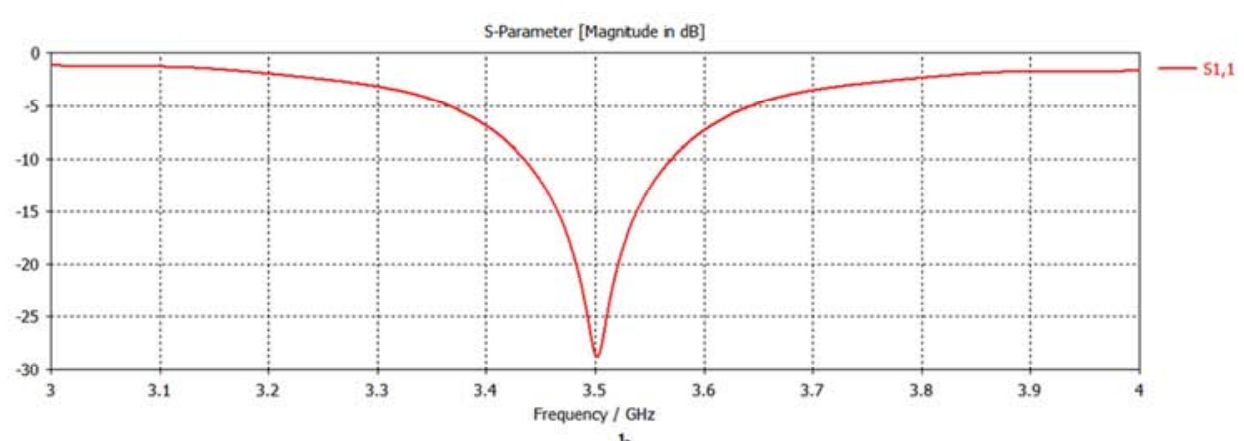

b 

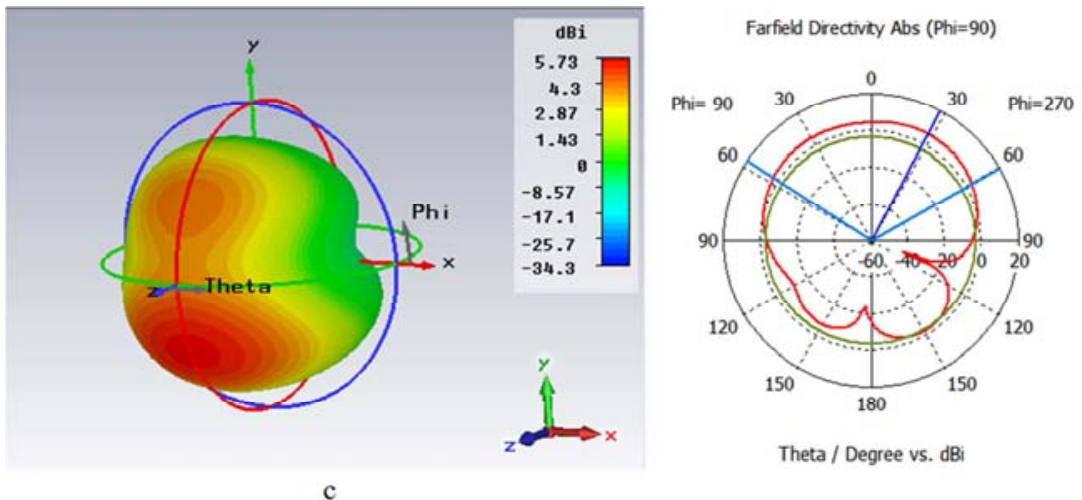

d

Figure 1. a. Representation of a rectangular patch antenna with notches. b. Reflection coefficient S11 as a function of frequency. c. Patch antenna gain radiation pattern with notches. $d$. Patch antenna directivity diagram with notches.

\section{Design and Simulation of Metamaterial Cells}

\subsection{Design and Simulation of the SRR Cell}

Figure 2 shows the SRR cell and its reflection coefficient S11 as a function of the resonant frequency of the patch antenna. The different dimensions of the SRR are given in Table 1 [9].

Table 2. Dimensions of the SRR.

\begin{tabular}{llll}
\hline Substrate length Ls & Substrate height Hs & Spacing between rings S & S Ring thickness W \\
\hline $5.55 \mathrm{~mm}$ & $1.56 \mathrm{~mm}$ & $0.15 \mathrm{~mm}$ & $0.2 \mathrm{~mm}$ \\
\hline
\end{tabular}

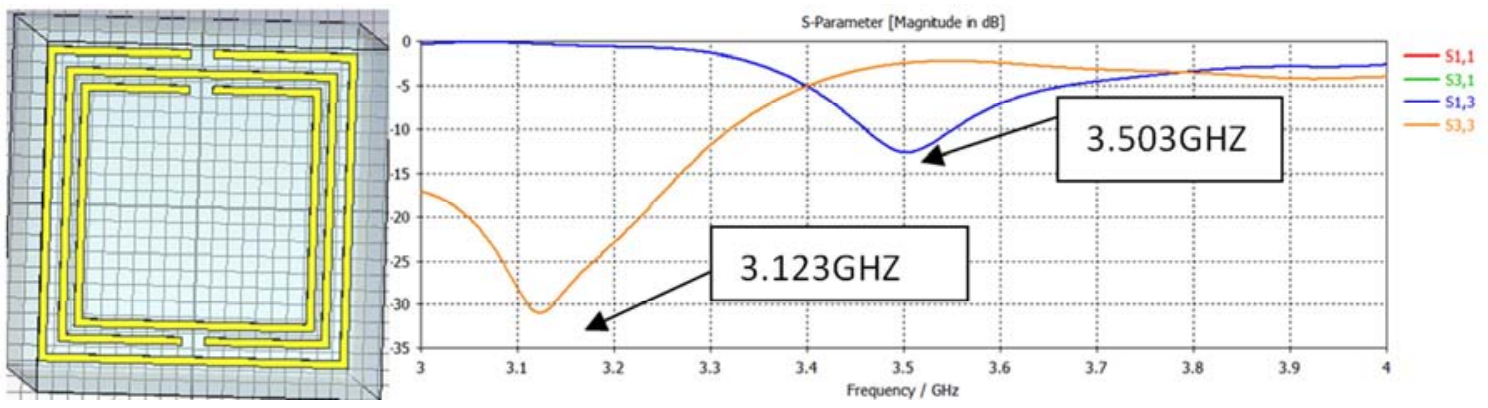

Figure 2. Representation of a 3-ring SRR unit with opposite openings and its S-parameters.

Figure 2 shows the evolution of the S11 reflection and S21 transmission coefficients as a function of the resonant frequency of the SRR [10]. We notice that the designed SRR has a transmission lower than $-14 \mathrm{~dB}$ for a frequency of $3.50 \mathrm{GHz}$ and a reflection coefficient of $-30.96 \mathrm{~dB}$ for a frequency of $3.123 \mathrm{GHz}$.

\subsection{Design and Simulation of the CSRR Cell with 3 Rings with Opposite Openings}

Figure 3 shows the 3-ring CSRR cell with opposite openings. The 3 concentric interrupted metallic rings (copper) engraved on a dielectric support (Substrate) [11].
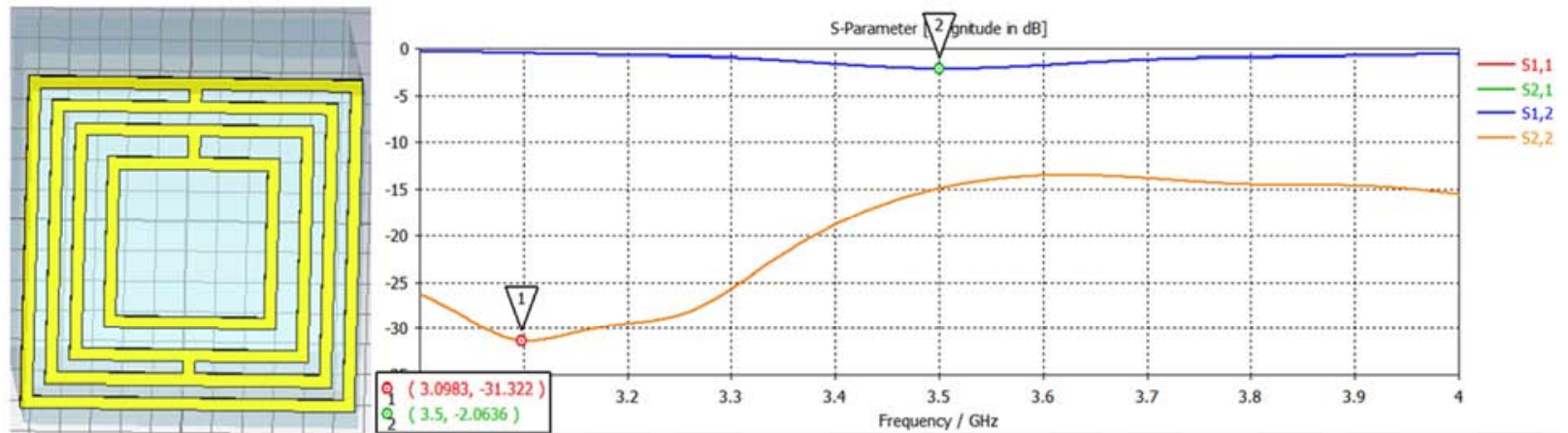

Figure 3. Representation of a 3-ring CSRR unit with opposite openings and its S-parameters. 
We notice that the CSRR presents a reflection coefficient S11 of $-31 \mathrm{~dB}$ for a frequency of $3.104 \mathrm{GHz}$ and a transmission $\mathrm{S} 21$ of $-2.06 \mathrm{~dB}$ for a frequency of $3.5 \mathrm{GHz}$, according to figure 3 .

Table 3. Values of the reflection coefficients for different patch antennas with different positions and numbers of CSRR cells on patch and ground plane.

\begin{tabular}{lll}
\hline $\begin{array}{l}\text { CSRR position on patch } \\
\text { and PDM }\end{array}$ & Fréquency $(\mathbf{G H z})$ & S-Paramèters (dB) \\
\hline 2 CSRR verticals on patch & 3.269 & -28.467 \\
2 CSRR horizontals on patch & 3.417 & -27.23 \\
2 CSRR verticals on PDM & 3.212 & -37.13 \\
1 CSRR on patch & 3.288 & -29.66 \\
1CSRR on PDM & 3.45 & -25.69 \\
\hline
\end{tabular}

\subsection{Interpretation of Simulation Results Before Adaptation}

The parameters of the different antenna configurations depending on the number and the position of the CSRR cells used in table 3 . This table represents the different positions and numbers of CSRR cells engraved on the patch and ground plane or both at the same time with the resonant frequency and the reflection coefficient (S11).

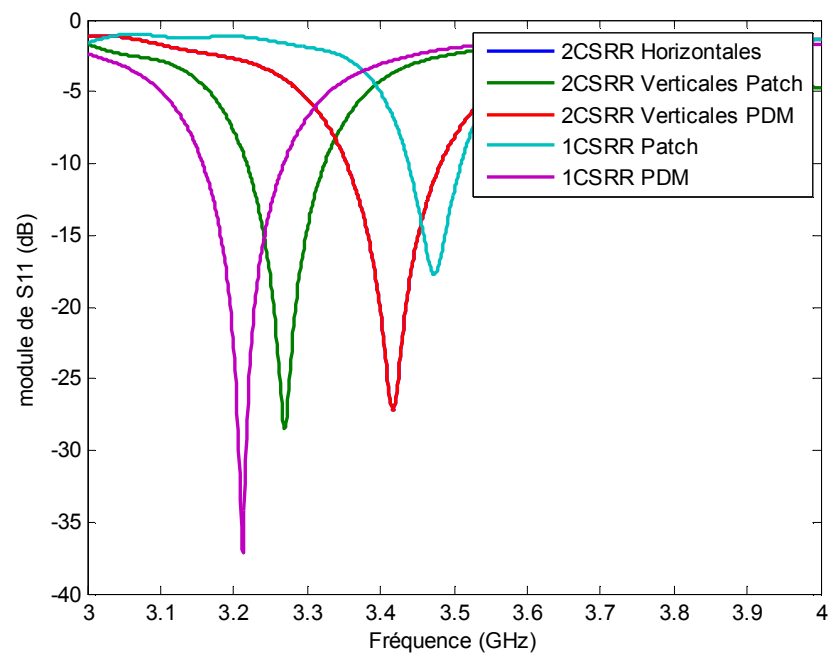

Figure 4. Coefficient S11 as a function of frequencies for different antennas loaded with 3-ring CSRRs with opposite openings before adaptation.
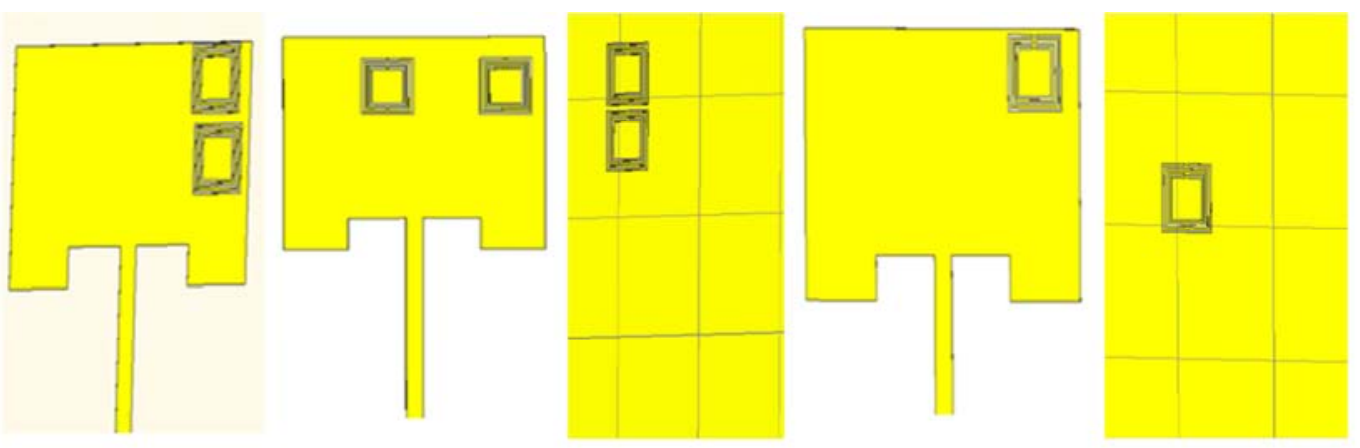

Figure 5. Representation of patch antennas loaded with CSRR with 3 rings with opposite openings.

Table 4. Values of the reflection coefficients for different patch antennas with different positions of CSRR cells on patch and ground plane.

\begin{tabular}{lll}
\hline CSRR position on patch and PDM & Fréquency $(\mathbf{G H z})$ & S-Paramèters (dB) \\
\hline 2 CSRR verticals on patch & 3.509 & -28.20 \\
2 CSRR horizontals on patch & 3.506 & -29.79 \\
1 CSRR on PDM & 3.45 & -25.69 \\
1 CSRR on patch & 3.501 & -30.088 \\
\hline
\end{tabular}

\subsection{Interpretation of Antenna Simulation Results After Adaptation}

The parameters of the different antenna configurations depending on the number and position of CSRR cells used are presented in Table 4 which shows the position of the CSRR cells on the patch or the ground plane (PDM) with the resonant frequency and the reflection coefficient (S11).

The results of the $\mathrm{S}$ parameters of the previous antennas show band-cut behavior at the $3.5 \mathrm{GHz}$ frequency, corresponding to the resonant frequency of the CSRR cell after optimization and modification of the antenna parameters.

The best optimizations for the different positions of the CSRR cells with their miniaturization rates, their efficiencies and their bandwidth widths are given in Table 5 at the frequency $3.5 \mathrm{GHz}$.

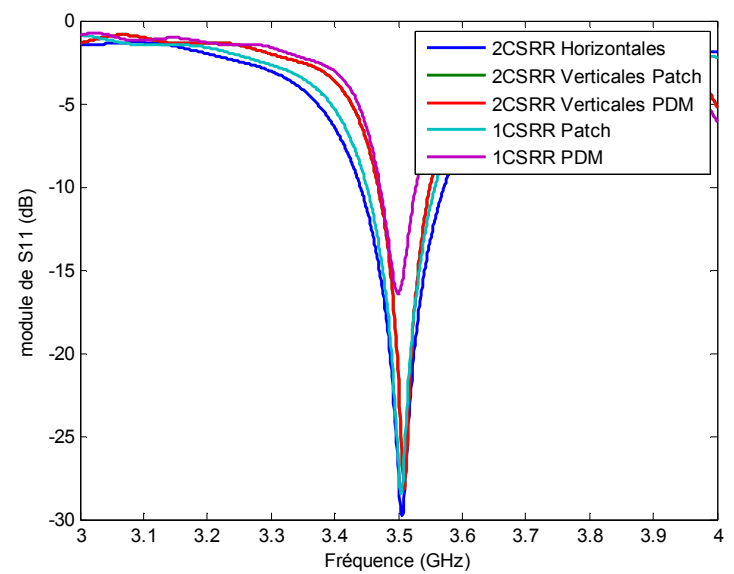

Figure 6. Coefficient S11 as a function of frequencies for different antennas loaded with 3 ring CSRRs with opposite openings after adaptation. 
Table 5. Values of miniaturization rates, yields and bandwidths for the different antennas with CSRR engraved on patch and / or PDM.

\begin{tabular}{llll}
\hline CSRR position on patch and PDM & Miniaturization rate (\%) & efficiency (\%) & Bandwidth (\%) \\
\hline 2 CSRR verticals on patch & 18.5 & 2.28 & 8 \\
2 CSRR horizontals on patch & 18.58 & 3.7 & 13 \\
1 CSRR on PDM & Pas d'adaptation & 1.99 & 7.2 \\
1 CSRR on patch & 13.79 & 2.57 & 9 \\
2 CSRR verticals on PDM and patch & Pas d'adaptation & 2.3 & 7.15 \\
\hline
\end{tabular}

Table 6 shows the parameters of the patch antenna after adaptation.

Table 6. Parameters of the patch antenna after adaptation.

\begin{tabular}{lllll}
\hline CSRR position on patch & Wp $(\mathbf{m m})$ & $\mathbf{L p}(\mathbf{m m})$ & $\mathbf{W g}(\mathbf{m m})$ & $\mathbf{L g}(\mathbf{m m})$ \\
\hline 2 CSRR verticals on patch & 25.6 & 18.04 & 35.65 & 76 \\
2 CSRR horizontals on patch & 25.7 & 19.945 & 35.65 & 76 \\
1 CSRR on PDM & 28 & 20.26 & 35.65 & 72.74 \\
1 CSRR on patch & 26.68 & 18.333 & 35.8 & 79.88 \\
2 CSRR vertical on PDM and patch & 28 & 20.26 & 35.65 & 72.74 \\
\hline
\end{tabular}

\subsection{Interpretation of Antenna Simulation Results After Adaptation}

The gain values before and after adaptation for the different antenna configurations depending on the number and position of the CSRR cells are presented in Table 7.

Table 7. Values of the gain of the patch antenna before and after adaptation.

\begin{tabular}{lll}
\hline CSRR position on patch and PDM & Gain before adaptation & Gain after adaptation \\
\hline 2 CSRR verticals on patch & 6.1 & 5.9 \\
2 CSRR horizontals on patch & 6.21 & 5.97 \\
2 CSRR verticales on PDM & 5.61 & 5.61 \\
1 CSRR on patch & 5.33 & 5.33 \\
1 CSRR on PDM & 6.14 & 6.14 \\
\hline
\end{tabular}

After simulating the different patch antennas with different positions and numbers of CSRR cells on patch or ground plane or on both sides of the antennas at the same time, we notice that the gain values obtained before adaptation of the antennas are higher than those after adaptation.

\subsection{Comments Before and After Adaptation of the Patch Antenna}

Table 8. Comments on the figures.

\begin{tabular}{|c|c|c|}
\hline $\begin{array}{l}\text { CSRR position on } \\
\text { patch and PDM }\end{array}$ & Before adaptation & After adaptation \\
\hline $\begin{array}{l}2 \text { CSRR verticals } \\
\text { on patch }\end{array}$ & $\begin{array}{l}\text { Very good reduction in frequency to } 3.269 \mathrm{GHz} \text { with a reflection coefficient of } \\
-28.46 \mathrm{~dB} \text { Resonance frequency and desired reflection coefficient }-31 \mathrm{~dB} \text { better } \\
\text { optimization. }\end{array}$ & $\begin{array}{l}\text { Resonance frequency and desired } \\
\text { reflection coefficient }-31 \mathrm{~dB} \text { better } \\
\text { optimization. }\end{array}$ \\
\hline $\begin{array}{l}2 \text { CSRR } \\
\text { horizontales sur } \\
\text { patch }\end{array}$ & $\begin{array}{l}\text { Reduction of the frequency to } 3.41 \mathrm{GHz} \text { with a coefficient of }-27.23 \mathrm{~dB} \text { Good } \\
\text { optimization of the resonant frequency and desired reflection coefficient }\end{array}$ & $\begin{array}{l}\text { Good optimization of the resonant } \\
\text { frequency and desired reflection coefficient }\end{array}$ \\
\hline $\begin{array}{l}\text { 2CSRR sur patch et } \\
\text { PDM }\end{array}$ & $\begin{array}{l}\text { Despite the frequency decrease to } 3.47 \mathrm{GHz} \text { the reflection coefficient is very far }-17 \mathrm{~dB} \text {. } \\
\text { Desired frequency of } 3.5 \mathrm{GHZ} \text { with a good reflection coefficient of }-30 \mathrm{~dB} \text {. }\end{array}$ & $\begin{array}{l}\text { Desired frequency of } 3.5 \mathrm{GHZ} \text { with a good } \\
\text { reflection coefficient of }-30 \mathrm{~dB} \text {. }\end{array}$ \\
\hline 1CSRR sur PDM & $\begin{array}{l}\text { A resonant frequency reduced to } 3.45 \mathrm{Ghz} \text { with a low reflection coefficient at }-25.69 \mathrm{~dB} \\
\text { Close to the resonant frequency but the very low reflection coefficient }-23 \mathrm{~dB} \text {. }\end{array}$ & $\begin{array}{l}\text { Close to the resonant frequency but the } \\
\text { reflection coefficient very low }-23 \mathrm{~dB} \text {. }\end{array}$ \\
\hline
\end{tabular}

\section{Design and Simulation of 3-ring SRR and CSRR Cells with Openings in the Same Direction}

Figure 7 shows the SRR cell. with 3 rings with openings in the same direction and the results of simulations of the S-parameters. 


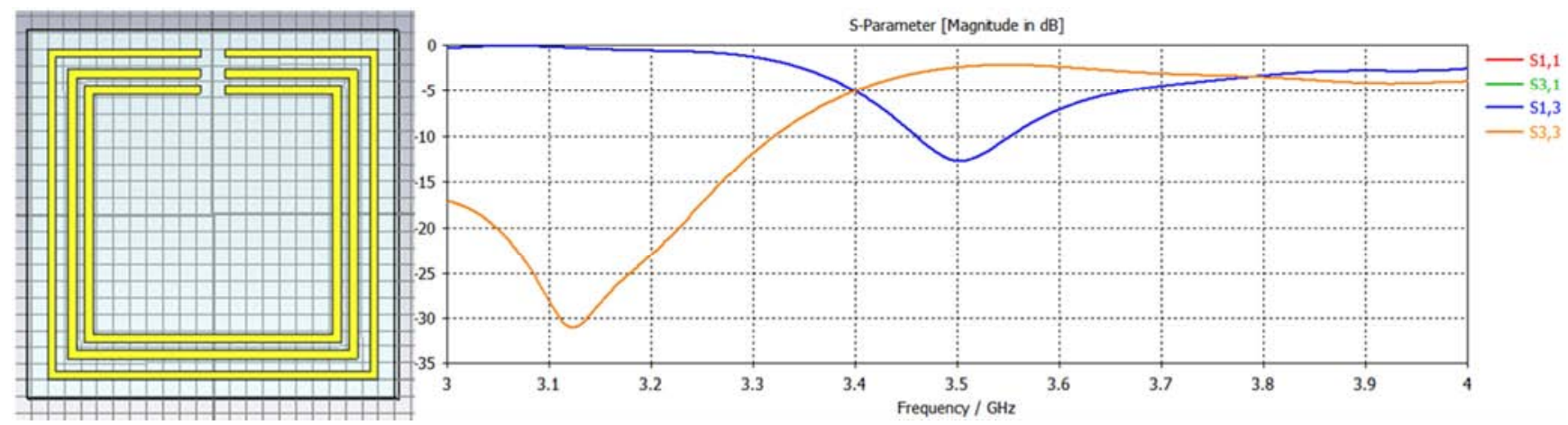

Figure 7. Representation of the 3-ring SRR with openings in the same direction.

Figure 7 illustrates the evolution of coefficients S11 and S21 as a function of the frequency of the SRR. We notice that the transmission coefficient is $-15 \mathrm{~dB}$ at the frequency $3.5 \mathrm{GHz}$ and a reflection coefficient of $-30.91 \mathrm{~dB}$ at the frequency $3.113 \mathrm{GHz}$.

\subsection{Design and Simulation of the 3-ring CSRR Cell with Openings in the Same Direction}

Figure 8 shows the 3 -ring CSRR with openings in the same direction. The 3 concentric interrupted metal rings are etched on a dielectric support (substrate).
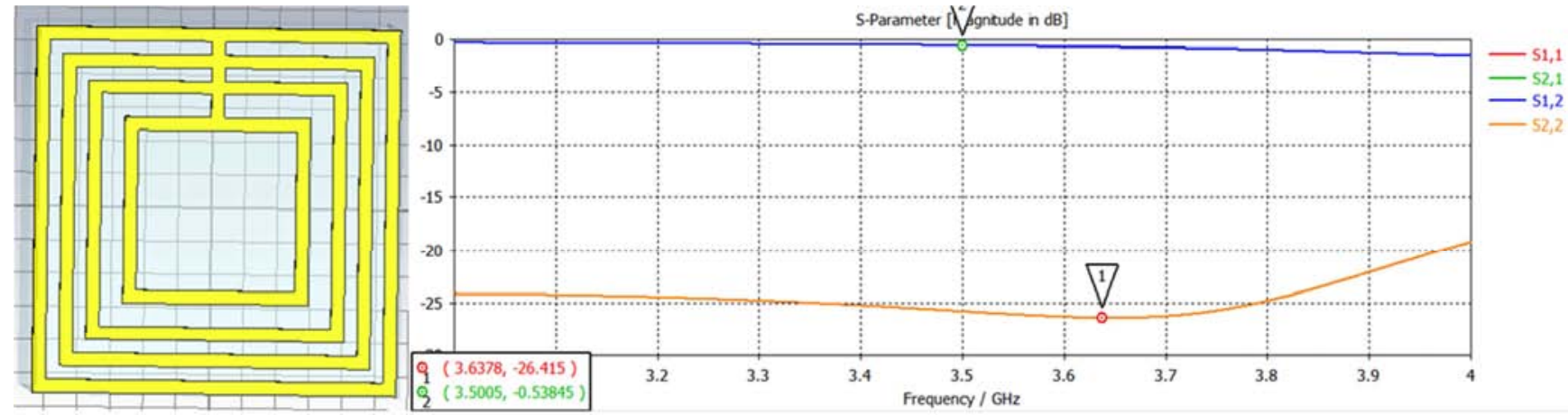

Figure 8. Representation of the 3-ring CSRR with openings in the same direction and the different -S parameters.

Table 9. Value of the reflection coefficient for the patch antenna with position of the 3 ring CSRR cell with openings in the same direction before adaptation.

\begin{tabular}{lll}
\hline CSRR position on patch & Fréquency (GHz) & S-Paramèters (dB) \\
\hline 1 CSRR with 3 rings with openings in the same direction & 3.288 & -29.66 \\
\hline
\end{tabular}

We notice that the CSRR has a transmission coefficient $\mathrm{S} 21$ of $-2.07 \mathrm{~dB}$ at $3.5 \mathrm{GHz}$.

\subsection{Interpretation of Simulation Results Before Adaptation}

The parameters of the different antenna configurations depending on the number and position of CSRR cells used are shown in the table which shows the position of the CSRR cells on the patch with the resonant frequency and the reflection coefficient (S11).
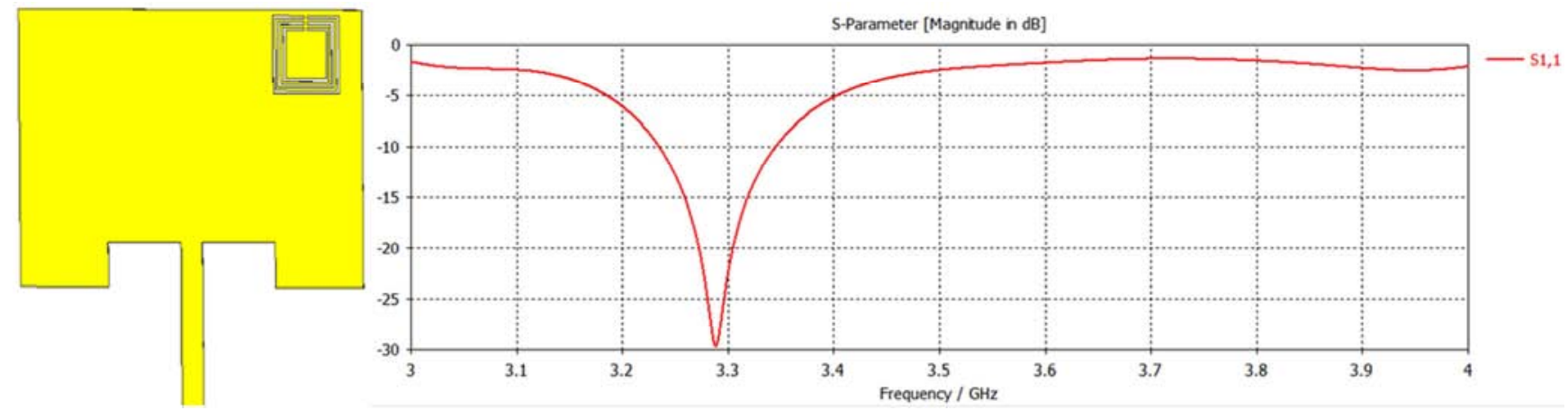

Figure 9. Patch antenna with 1 CSRR and its coefficient S11 as a function of frequency. 


\subsection{Interpretation of Antenna Simulation Results After Adaptation}

The parameters of the different antenna configurations depending on the number and position of CSRR cells depending on the frequency and the reflection coefficient (S11) are shown in Table 10.

Table 10. Value of the reflection coefficient for a patch antenna with 3-ring CSRR cell position with openings in the same direction after adaptation.

\begin{tabular}{lll}
\hline CSRR position on patch & Fréquency $(\mathbf{G H z})$ & S-Paramèters $(\mathbf{d B})$ \\
\hline 1 CSRR with 3 rings with openings in the same direction. & 3.501 & -30.088 \\
\hline
\end{tabular}

The results of the $\mathrm{S}$ parameters in the previous figures show band-cut behavior around $3.5 \mathrm{GHz}$, corresponding to the resonant frequency of the CSRR cell after optimization and modification of the antenna parameters.

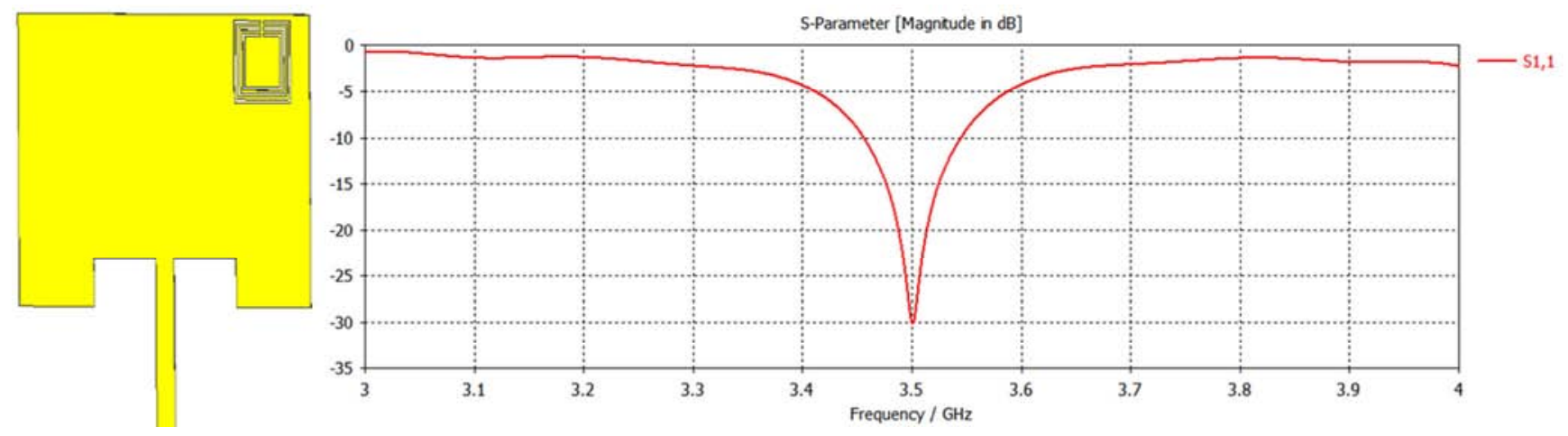

Figure 10. Patch antenna with 1 CSRR and its coefficient S11 as a function of frequency.

The best optimizations obtained from the different positions and numbers of CSRR cells with their miniaturization rates, efficiencies and bandwidth widths are given in Table 11.

Table 11. Value of the miniaturization rate, the efficiency and the bandwidth for a patch antenna with 3-ring CSRR with openings in the same direction.

\begin{tabular}{llll}
\hline CSRR position on patch & Miniaturization rate (\%) & efficiency (\%) & Bandwidth (\%) \\
\hline 1 CSRR with 3 rings with openings in the same direction & 13.79 & 2.57 & 9 \\
\hline
\end{tabular}

Table 12 shows the new parameters of the patch antenna after adaptation.

Table 12. Parameter of the patch antenna after adaptation.

\begin{tabular}{lllll}
\hline CSRR position on patch & Wp $(\mathbf{m m})$ & $\mathbf{L p}(\mathbf{m m})$ & $\mathbf{W g}(\mathbf{m m})$ & $\mathbf{L g}(\mathbf{m m})$ \\
\hline 1 CSRR with 3 rings with openings in the same direction & 26.68 & 18.333 & 35.8 & 79.88 \\
\hline
\end{tabular}

\subsection{Interpretation of the Gain Results Before and After Adaptation}

The gain values for this antenna configuration as a function of the positions of the CSRRs are shown in Table 13 which represents the position of the 3-ring CSRR cells with openings in the same direction on the patch and the gain values before and after adaptation.

Table 13. Values of the gain of the patch antenna before and after adaptation.

\begin{tabular}{lll}
\hline CSRR position on patch & Gain before adaptation & Gain after adaptation \\
\hline 1 CSRR with 3 rings with openings in the same direction & 6.09 & 5.7 \\
\hline
\end{tabular}

After simulation of patch antennas with different positions and number of CSRR cells on patch, we notice that the gain values before adaptation of the antennas are higher than those obtained after adaptation.

\subsection{Comments Before and After Adaptation}

Table 14. Comments on the figures.

\begin{tabular}{lll}
\hline CSRR position on patch & Before adaptation & After adaptation \\
\hline \multirow{2}{*}{ C CSRR with 3 rings with openings in the same direction } & $\begin{array}{l}\text { Very good frequency reduction at 3.288GHZ } \\
\text { with a coefficient of }-29.66 \mathrm{~dB} .\end{array}$ & $\begin{array}{l}\text { Desired resonance frequency of 3.501GHZ } \\
\text { with a good coefficient S11=-30.88dB. }\end{array}$ \\
\hline
\end{tabular}




\section{Conclusion}

It was possible to model a patch antenna using the electromagnetic software Microwave Studio (CST). This modeling made it possible to study the influence of various parameters of the rectangular patch antenna radiation patterns for $5 \mathrm{G}$ applications.

The design of the different patch antennas loaded with 3-ring CSRR metamaterial resonators with opposite openings and openings in the same direction are set to have a good response at the resonant frequency of $3.5 \mathrm{GHz}$. The resonance response of these structures varies according to the number and the position of the CSRR resonators, whether on the patch or on the ground plane.

Subsequently, we confirmed that the choice of the position and the number of cells relative to the antenna, is an important condition in order to optimize the level of coupling and to ensure the desired metamaterial effect. The simulation results obtained confirm the obtaining of a better result of reflection coefficients, miniaturization rate, efficiency and gain at the frequency $3.5 \mathrm{GHz}$ for the antennas loaded with 3-ring CSRRs with opposite apertures. The bandwidth varies from $83 \mathrm{MHz}$ to $94 \mathrm{MHz}$ with a reflection coefficient that varies between $-25.7 \mathrm{~dB}$ and $-37.8 \mathrm{~dB}$, depending on the position and number of CSRRs on the antenna.

The goal of this work is to miniaturize patch antennas using CSRR cells embedded on the patch or on the ground plane. Antenna miniaturization technology minimizes the cost and also the gain in materials and surfaces to be used.

\section{References}

[1] R. SHEKHAR, "Network architecture of 5G mobile technology", Article rédigé dans http://fr.slideshare.net/vineetkathan/5gwirelesssyste, 2013.

[2] Titu-Marius I. BAJENESCU. "5G: The Network of the future. Benefits and Perils", Electrotehnica, electronica, Automatic (EEA), 68 (2020), nr. $3, \quad$ PP75-79. https://doi.org/10.46904/eea.20.68.3.1108009.

[3] R. Cetkovic, «Les avantages de la 5G simplement», Article rédigé dans

https://www.journaldunet.com/ebusiness/telecoms-fai/142042

7-les-avantages-de-la-5gsimplement/\#, 20/12/2018.

[4] Réseaux 5G «Les avantages et les inconvénients», Article rédigé dans https://www.prixtel.com/decouvrir-prixtel/actualite/news/resea u-5g-les-avantages-et-les-inconvenients/, 24 juin 2019.

[5] «Grands dossiers fréquence 5G: procédure d'attribution de la bande [-3.4-3.8] $\mathrm{GHz}$ en métropole», Article rédigé dans https://www.arcep.fr/la-regulation/grands-dossiers-reseaux-mo biles/la-5g/frequences-5g-procedure-dattribution-de-la-bande34-38-ghz-en metropole.html.

[6] PASCAL. E, CHIEF. B, «Rand Officer chez Connecthings 5 applications de la $5 \mathrm{G}$ au service de la mobilité dont on ne parle jamais», Article rédigé dans https://www.usine-digitale.fr/article/5-applications-de-la-5g-a u-service-de-la-mobilite-dont-on-ne-parle-jamais.N826915, publié le 04 avril 2019.

[7] A. NIANG, «Antennes miniatures et structures électromagnétiques avec circuits non-Foster», THESE DE DOCTORAT En Physique, Université Paris-Saclay préparée a l’Université Paris-Sud ”, 09 Janvier 2017.

[8] A. JOHN WILEY. SONS «Electromagnetic metamaterials: transmission line theory and microwave applications the engineering», Livre public in Canada, 2006.

[9] S. NAWAZ.BUROKUR, «Mise en œuvre de métamatériaux en vue d'application aux circuits microondes et aux antennes», thèse de Doctorat en Electronique, Université De Nantes Ecole Doctorale, Novembre 2005.

[10] S. LANNEBRE, «Étude théorique de métamatériaux formés de particules diélectriques résonantes dans la gamme submillimétrique: magnétisme artificiel et indice de réfraction négatif», Thèse pour Obtenir le garde Docteur En Electronique, Université bordeaux 1, 03 Novembre 2011.

[11] R. GHASEMI, «Métamatériaux en infrarouge et applications», Thèse de Doctorat, discipline physique, Université Paris-Sud, 11Novembre 2012.

[12] Tomas PALENIK, Rene HARTANSK, Miki BITTERA, Jozef HALLON, Karol KAVAC. "Numerical Input Impedance Analysis of Loop Antennas “. Electrotehnica, electronica, Automatic (EEA), 59 (2011), nr. 3, PP21-25. 